Sectarianism in Scotland 



\section{Sectarianism in Scotland}

STEVE BRUCE, TONY GLENDINNING, IAIN PATERSON AND MICHAEL ROSIE 
(C) Steve Bruce, Tony Glendinning,

Iain Paterson and Michael Rosie, 2004

Transferred to digital print 2011

Edinburgh University Press Ltd

22 George Square, Edinburgh

Typeset in Bembo by

Hewer Text Ltd, Edinburgh, and

Printed and bound in Great Britain by

CPI Antony Rowe, Chippenham and Eastbourne

A CIP record for this book is available from the British Library

ISBN 0748619119 (paperback)

The right of Steve Bruce, Tony Glendinning,

Iain Paterson and Michael Rosie to be identified

as authors of this work has been asserted in accordance

with the Copyright, Designs and Patents Act 1988. 